\title{
The Online Study Practices of Secondary Ashramic Students of WestBengal in Covid Scenario
}

\author{
Swapan Kumar Nag ${ }^{1} \&$ Dr. Sadhana Pandey ${ }^{2}$ \\ ${ }^{1}$ Research Scholar, Dept. of Education \\ CSJM University, Kanpur, India. \\ ${ }^{2}$ Research Guide, Dept. of Education \\ CSJM University, Kanpur, India.
}

\begin{abstract}
:
Objective: The prime focus of the paper is to search out the impact of on-line study practices on students from the secondary ashrams of province throughout the Pandemic. The paper studied the impact in two completely different localities i.e., north and south twenty-four Parganas. Study habits perpetually have a motivating influence on the student's engagement and learning experiences. Therefore, this study can confirm the impact of on-line study practices on students from the secondary ashrams of province in the Covid period.
\end{abstract}

Methodology: The study is Descriptive survey nature wherever stratified sampling techniques adopted for choosing the respondents from the study area of West Bengal. Theentire number of respondents was 201. As a search, instrument investigator used three verydifferent tools- three successful form tools used for assembling responses from the respondents. First form deals with the size of on-line engagement, the second deals with the online learning experience, and finally with the dimension of on-line study practices. The information analyzed with the assistance of descriptive and inferential statistics by using SPSS software system.

Result: The findings of the study reveals that there is significant relationship between variables. It is found that both the localities of students does vary significantly in online engagement, online learning experience and online study habit. High positive correlation prevail between online engagement and online learning experience with $r=.873$.

Keywords: Online Study practices, online engagement, online learning experience, Ashram schools, secondary students. Pandemic situation. 


\section{Introduction}

The construct of 'Ashram School' derived from the term "Ashram" that has its origins in ancient India. It known to be as the "Household of the teacher". In one sense, the guru and his better half provided care and support to the scholars that are contributory for his or her enrichment of privatelife. The origin of the Ashram School functioning initiated within the state of Gujarat. It is the basic education or new employment scheme of Mohandas Karamchand Gandhi. The Kocharab Ashram and therefore the castaway Ashram established by Mohandas Karamchand Gandhi in Gujarat is marvelous samples of this. The basics of basic education among the ashram college havecome from these ashrams. Gandhiji's main objective behind establishing the ashram was to arrangefreedom fighters for the liberation struggle and to run constructive programs. Later, Mohandas Karamchand Gandhi to boot joined basic education with ashram life. Such school that are lapsed State Governments are a significant tool to supply formal education to ST Offsprings. Among the Sixties, Ashram faculty started on an experimental basis. According to Dewey (1926) Education could be a continuous method of experiencing and editing or non-revising experiences. "It is the development of all those capacities in the individual, which enable him to control his environment and fulfill his possibilities" (Y.K.Singh, p.22). The pandemic has necessitated on-line teaching that has been obligatory upon several for whom it had been solely unacquainted, however conjointly undesirable. As social distancing and internment became public policies to arrest the spread of wicked malady, ancient modes of education swapped for the additional technology- intensive and nuanced on-line platforms.

According to a UNESCO report, .38 billion learners worldwide suffering from national faculty closures initiated within the aftermath of COVID-19. Many toughened the new on-line mode of education for the primary time, whereas others with previous exposure to the present field long-faced full-fledged on-line exams and lectures for the primary time. On-line learning could be a term that encompasses web-based teaching, e-learning, distributed learning, net-based learning, web-based coaching, cyber learning, virtual learning, and internet-based learning (Urban and Wegen, 2000). A pointy divide is obvious between urban-rural segments within the resources onthe market to avail on-line education services. Locations that area unit removed from major urbanareas or at a big elevation higher than mean water level have poor network and property. Studentsdrawn from varied rural and peri-urban areas towards urban areas to receive education (Mahadev \& kumaran, 1998). Tasks undertaken by an online coach completely different from those of a conventional teacher. Face-to-face interaction that an everyday room offers is inaccessible in an internet session. Mere physical presence might satisfy during a regular room. However, the web model leaves the student with the superimposed responsibility of getting smart readiness levels, with a soundly functioning device, web property that permits for effective audiovisual reception and transmission. Therefore, the many impact of the dynamical education system falls on the scholars. With the exception of the disruption of the tutorial calendar, career plans, and potential job loss, students face variety of alternative problems as results of the web system. One facet of this pertains to the technicalities of on-line learning, like loss of interactivity, lack of access to review material, improper infrastructure, etc. Loss of formal education and ancient ways bridged by on-line 
ways to confirm continuity of growth in human capital potential. Home schooling couldseem like an alternative. However, completely students coming back from different backgrounds can have unequal opportunities because of variations in family financial gain, access to resources, parents' level of education, and the ability of guardians to devote time to teaching their kids. During a country like Republic of India, wherever deprivation is rampant, this may heavily ostracize the marginalized sections. Of these have really affected the study habits of scholars. Because of imprisonment, the residential students sent back to their home places, most of them void of such opportunities and privileges, and as a result, it affected their performance. School orinstitutions adopted relevant technologies, ready learning and employees resources, set systems and infrastructure, established new teaching protocols, and adjusted their curricula. However, thetransition was sleek for a few colleges however rough for others. Therefore, the scientist, throughher investigation, can highlight the above-named major problems. Therefore, the researcher, through her investigation, will highlight the above-mentioned major issues.

\subsection{Conceptual Framework}

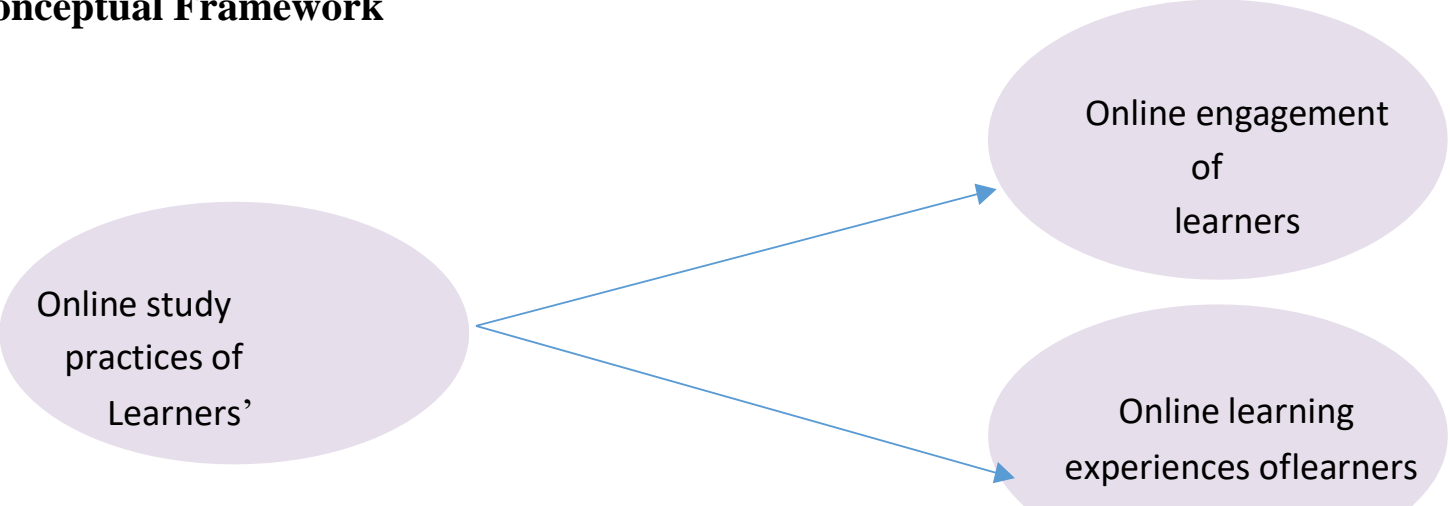

Figure 1: Showing the conceptual Framework

Source: Created by investigator

The online study practices of learners depends upon the online engagement i.e., engagement can be defined as a measure of a student's participation in the learning process. This includes their interaction and cooperation with the teacher and classmates. It also include learner teacher interaction, learner-learner interaction and content-learner interaction. These elements affects theonline study habits of learners. These practices includes actions like, online reading, online takingnotes, holding study groups, which the students perform regularly, and habitually in order to accomplish the task of learning. Study practices described as effective or ineffective depending upon whether or not they serve the students well. Good study skills can increase your confidence,competence, and self-esteem. They can also reduce anxiety about tests and deadlines. By developing effective study skills, you may be able to cut down on the numbers of hours spend studying, leaving more time for other things in your life. Online learning experience includes structured course or learning experience delivered electronically; it can also include performancesupport content, clarification about project or assignment, facing technical issues, provision of on-demand access, use of gamification for learner engagement etc. Therefore, through the investigation the researcher tries to find out effect of online study practices of learners during Covid period. 


\subsection{Need and Significance of Study}

The Information and communication technologies that have an effect on all spheres of life are alsoactively included in the education field. With the recent developments, using technology in education has become inevitable due to personal and social reasons (Usta, 2011). The period of Covid-19 pandemic has emerged as a sudden state of having limited opportunities. Face to face, education has stopped in this period for a long time. The global spread of Covid-19 affected morethan 850 million students all around the world, and it caused the suspension of face-to-face education. Different countries have proposed several solutions in order to maintain the education process during the pandemic. Schools have had to change their curriculum, and many countries supported the online education practices soon after the pandemic. In other words, traditional education gave its way to online education practices. At least 96 countries have been motivated toaccess online libraries, TV broadcasts, instructions, sources, video lectures, and online channels. The general impact of online study habit on an online engagement and online learning experiences discovered in the study. Therefore, this will provide an opportunity to get a general overview of the online education, which practiced, and discussed intensively in pandemic scenario. Moreover, the general impact of online study habits on secondary ashramic students analyzed, considering different variables.

\subsection{Review of Literature}

- Fjelstul, J. (2006). The impact of online education on academic performance for LPGA teaching and club professionals. University of Central Florida. Suggested uses of this study include the future development of online review sessions for LPGA Class B and Apprentice written evaluations, with the goal of improving academic performances. Future research should include replication of the present study, but with a larger samplesize. Future research should also involve Class B and Apprentice test takers and not be limited to first time test takers.

- Xu, D., \& Jaggars, S. S. (2013). The impact of online learning on students' course outcomes: Evidence from a large community and technical college system. Using a largeadministrative dataset from a statewide system including 34 community and technical colleges, the authors employed an instrumental variable technique to estimate the impact of online versus face-toface course delivery on student course performance. The travel distance between each student's home and college campus served as an instrument for thelikelihood of enrolling in an online section of a given course. In addition, college-by- course fixed effects controlled for withinand between-course selection bias. Analyses yield robust negative estimates for online learning in terms of both course persistence andcourse grade, contradicting the notion that there is no significant difference between online and face-to-face student outcomes-at least within the community college setting. Accordingly, both two-year and four-year colleges may wish to focus on evaluating and improving the quality of online coursework before engaging in further expansions of online learning.

Nguyen, V. A. (2017). The impact of online learning activities on student learning outcome in blended learning course. Interactive activities are considered, in this study; include teacher - student interaction, student - student interaction, student - content interaction, and student technology interaction. The undergraduate student participated in the blended learning course which using formative assessment to evaluate student learning outcomes by the combination of 
different learning activities through a learning management system. The quantitative results obtained when implementing learning analytics data from the system through using regression analysis showed that the students interact effectively with learning activities in the coursehave better results. Quantitative analytical results indicate that student - student interaction has a greater impact on student learning outcomes.

- Salamat, L., Ahmad, G., Bakht, M. I., \& Saifi, I. L. (2018). Effects of E-learning on students' academic learning at university level. The study highlights the effects of e- learning on students' academic learning at university level. The objective of the studywas; to find out the effects of E-learning on students' interest and learning at university level. Researchers used quantitative research method for the study. The study found that E-learning provides time flexibility to the students and it motivates students to do their own work without others help. It was also that students feel comfortable when they use internet. The study concluded that elearning is a system that provide time flexibility to the students for their learning and motivates students to do their work without others help. It concluded that students feel comfort in browsing and surfing internet.

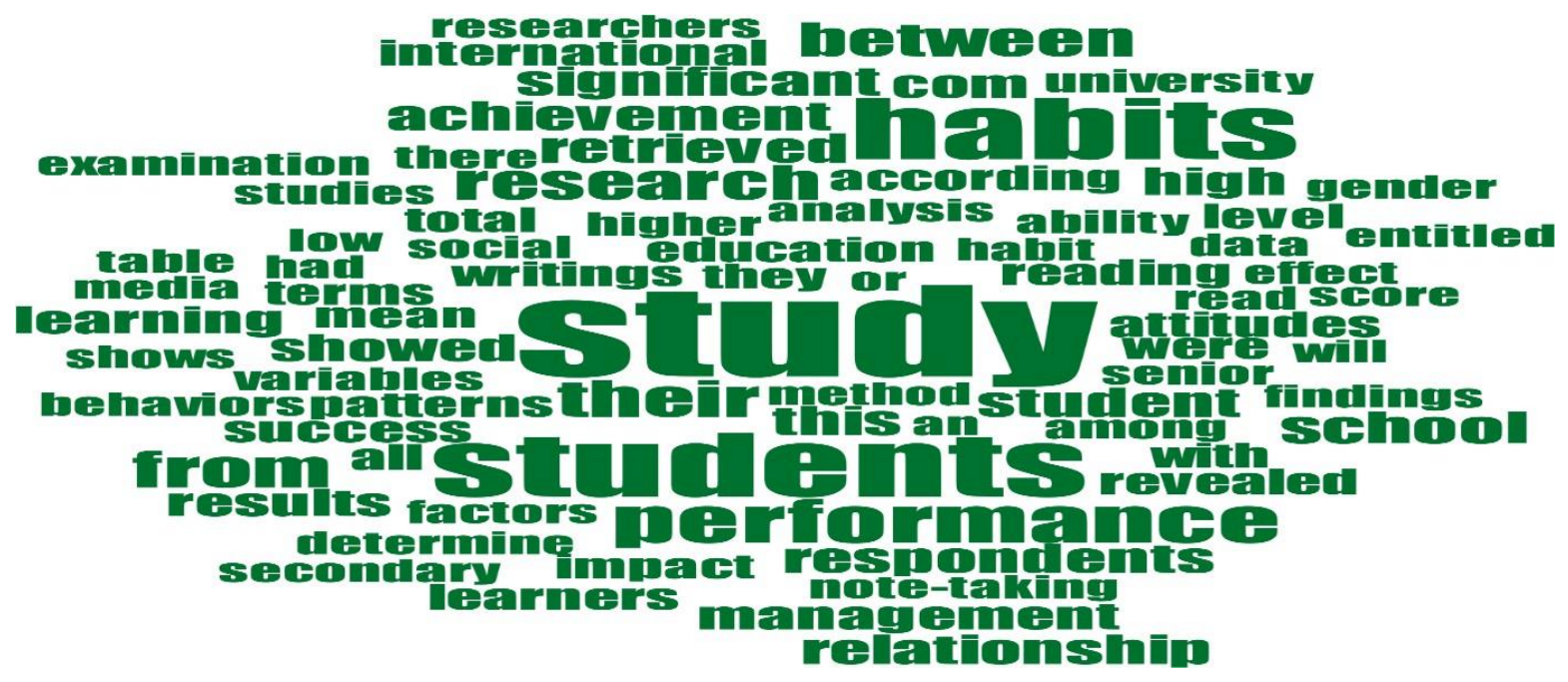

Figure 2: Showing the visual description of related review of literatureSource: Maxqda Software

From the review of related literature, it is visible that most frequent concurrent word is the study habit with 75 counts, students' performance with 63 counts, note taking and reading effect 43 counts, attitude with 30 counts, impact with 24 counts. It states that positive study habits improves student's performance. Positive study behaviors include note taking, reading time, timemanagement relationship etc.

\subsection{Research Gap:}

None or very limited studies have been conducted on the impact of online study habits of Ashramicschool of West Bengal during Covid period. Most of the study related to online education and academic performance of students. Therefore, researcher have decided to undertake a study relatedto online study practices Of Secondary Ashramic Students of West Bengal during Covid situation 


\subsection{Statement of Problem}

The Covid has brought a replacement transformation everywhere the planet. Different elements ofdeveloped countries were well aware of the web platform, as usually they conduct on-line categories for the aim of seminars, conferences, or educational ones. However, the trend of onlinecategories within the ancient system of college education was not frequent. It extremely created weird things for school students furthermore as teachers. On the transformation stage college boards determined to conduct on-line education so, the flow of education does not get stagnant. The trend of Ashramic school was terribly completely different from the opposite style of public school in state of West Bengal as a result of the prime criteria were face-to-face relation between teacher and student. Lecturers additionally share shut bonding with students. In such school, theymaintained a strict discipline that facilitate them to develop sensible study habits. However, in on-line education such protocols really maintained or not, worries interest. The problem related to "The Online Study Practices of Secondary Ashramic Students of West Bengal during Pandemic Situation"

\subsection{Objective of study}

The objectives of study are:

1. To determine the mean score difference between learners in online engagement.

2. To assess the mean score difference between learners in online experience.

3. To determine the association between online study habits of learners of different locality.

4. To determine the relationship between online engagement and online learning experiences of learners.

5. To determine the relationship between online engagement and online study habits of learners.

6. To determine the relationship between online learning experiences and online study habits.

\subsection{Formulation of Hypothesis}

The hypothesis of study are as follows:

Ho1: There is no significant difference in learner's mean scores on online engagement in respectof locality.

Ho2: There is no significant difference in learner's mean scores on online experience in respect of locality.

Ho3: There exist no significant association between online study habits of learners and their locality.

Ho4: There is no significant relationship between online engagement and online learning experiences of learners.

Ho5: There is no significant relationship between online engagement and online study habits oflearners. 
Ho6: There is no significant relationship between online learning experiences and online studyhabits.

\subsection{Variables of study}

The present study will highlight on the online study habit of Secondary Ashramic Students of WestBengal during Pandemic Situation". Therefore, the variables of the present study are as follows:

* Categorical Variables- Online study habit.

* Independent Variables- student engagement and learning experiences.

* Demographic Variables- locale of secondary schools (rural and urban).

* Intervening Variable- Distraction, lack of opportunities, unwillingness, lack of interest.

\subsection{Operational Definition}

\subsubsection{Online Study Habits:}

Online study habit related with habitual practices one uses to help them to study and learn. The ability of the learner to schedule his time, the plan of the study, the habit of concentration, note taking etc., with the help of electronic media.

\subsubsection{Ashramic Students:}

Ashram schools are residential schools, which impart education up to the secondary education to children. Here students receive free boarding and lodging for pursuing education in a congenial environment.

\subsubsection{Online Engagement}

Online engagement commonly defined as the interaction between people across a range of social networks. Online engagement defined as a measure of a student's participation in the online learning process. This includes their interaction and cooperation with the teacher and classmates in an online mode.

\subsubsection{Online learning Experience}

Online learning experience refers to any interaction, course, program, or other experience in whichlearning takes place with the help of social networking.

\subsection{Delimitation of Study}

\subsubsection{Area}

This type of study could been conducted in any area of the state of West Bengal. However, considering the in- depthness of the study it will be conducted in the district of North 24 Parganas and South 24 Parganas, districts of West Bengal. 


\subsubsection{Secondary Students Population}

This type of study could been conducted on the primary and junior secondary population belong to different public schools. However, it decided that, the study would conducted on the Secondary students of Ashramic schools of North 24 Parganas and South 24 Parganas districts ofWest Bengal.

\subsubsection{Conceptual Issues}

Academic achievement could been judged with reference to different concepts interlinked withit. However, in this study, levels of education, socio economic conditions and locational variations of the secondary students would been taken into account to estimate their online performance during pandemic.

\section{Analysis and Interpretation}

\subsection{Area of Study}

The study conducted in the districts of West Bengal.

\subsection{Target Population}

The total number of schoolchildren who were learning in Ashramic school in West Bengal in anonline means.

\subsection{Method of Data Collection}

The study made use of both primary and secondary data.

Primary data collected by applying the self-made tools of researcher and responses collected fromthe respondents through interviews. It refers to that data which is collected for a specific purpose from the field and are original in nature.

Secondary data collected through various web sources and expert opinion, various textbooks, websites, journals, dissertations, etc.

\subsection{Sample of the Study}

To estimate the sample size Krejcie and Morgan table used. For a given infinite population of thetotal sample size is 201 from different schools of West Bengal, which are Ashramic in nature. Todetermine the sample size investigator used the Morgan's Table with 5\% error of margin at 95\% confidence level (Morgan, 1970) to justify the authenticity of selected sample size.

\subsection{Sampling Technique}

Investigator used probability-stratified sampling techniques for data collection. Data, collected from primary sources, compiled from Quantitative analysis. This technique based on three criteria, which delineated below: 
- Firstly, the respondents must belong from the Ashramic schools.

- Secondly, they must belong to the West Bengal.

- Thirdly, they must be from the secondary level.

\subsection{Tools used for the study}

To conduct the study researcher will use self-made tools for measuring the dimensions of onlineengagement, study habits, learning experiences of secondary students of Ashramic schools.

Table 1: Demographic profile of respondents

\begin{tabular}{|c|c|c|c|}
\hline Sl.No. & Locality & No. of Respondents & Percentage \\
\hline 1 & North 24 Parganas & 101 & 50.2 \\
\hline 2 & South 24 Parganas & 100 & 49.8 \\
\hline
\end{tabular}

Source: Field Survey

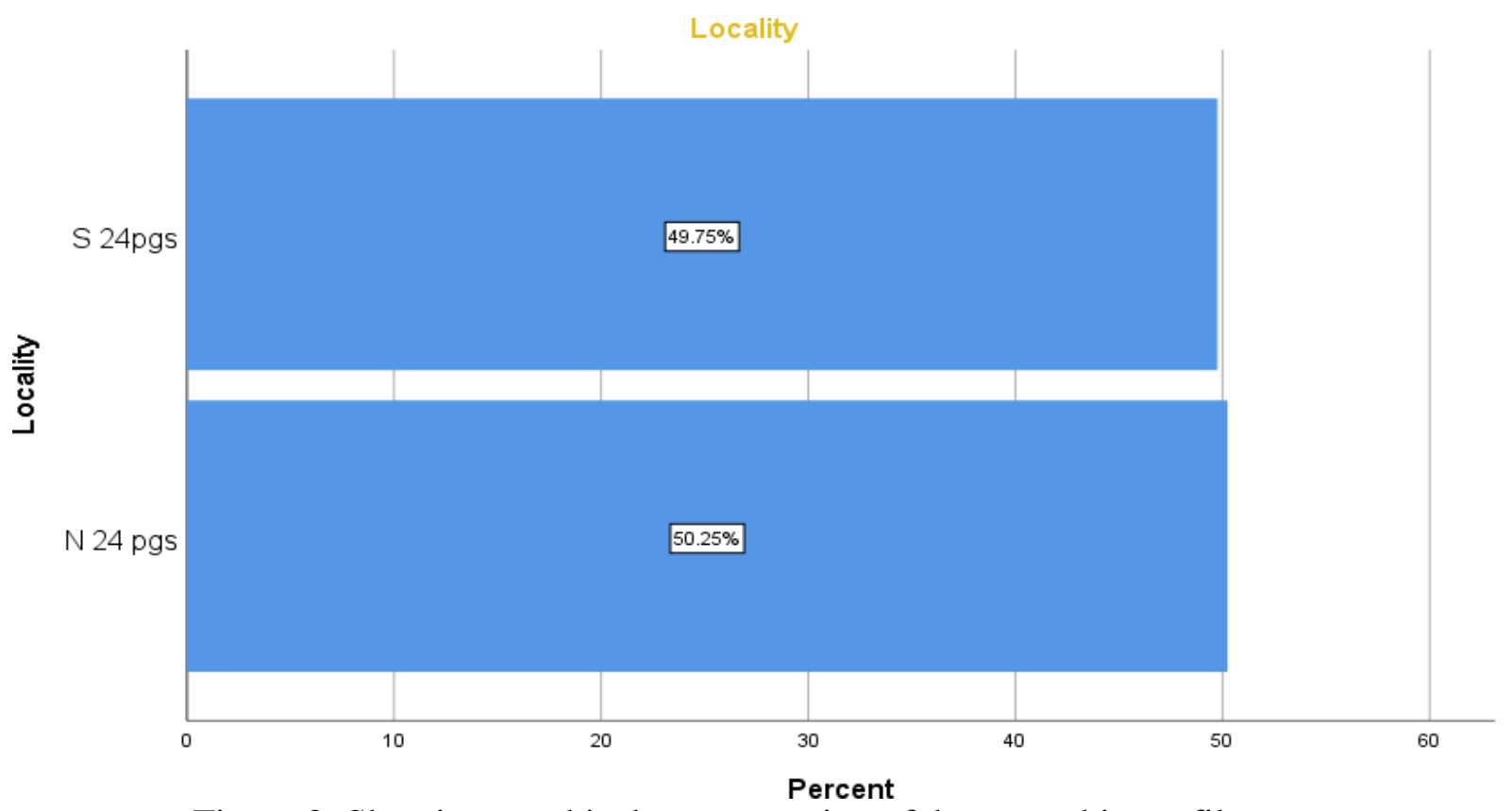

Figure 3: Showing graphical representation of demographic profile

\section{Analysis and Interpretation}

\subsection{Pertaining to hypothesis 1}

Ho1: There is no significant difference in learner's mean scores on online engagement in respectof locality.

To test the hypothesis t-test used by the investigator which showed in the table 2 . 
Table 2: showing the online engagement of learners in respect of locality

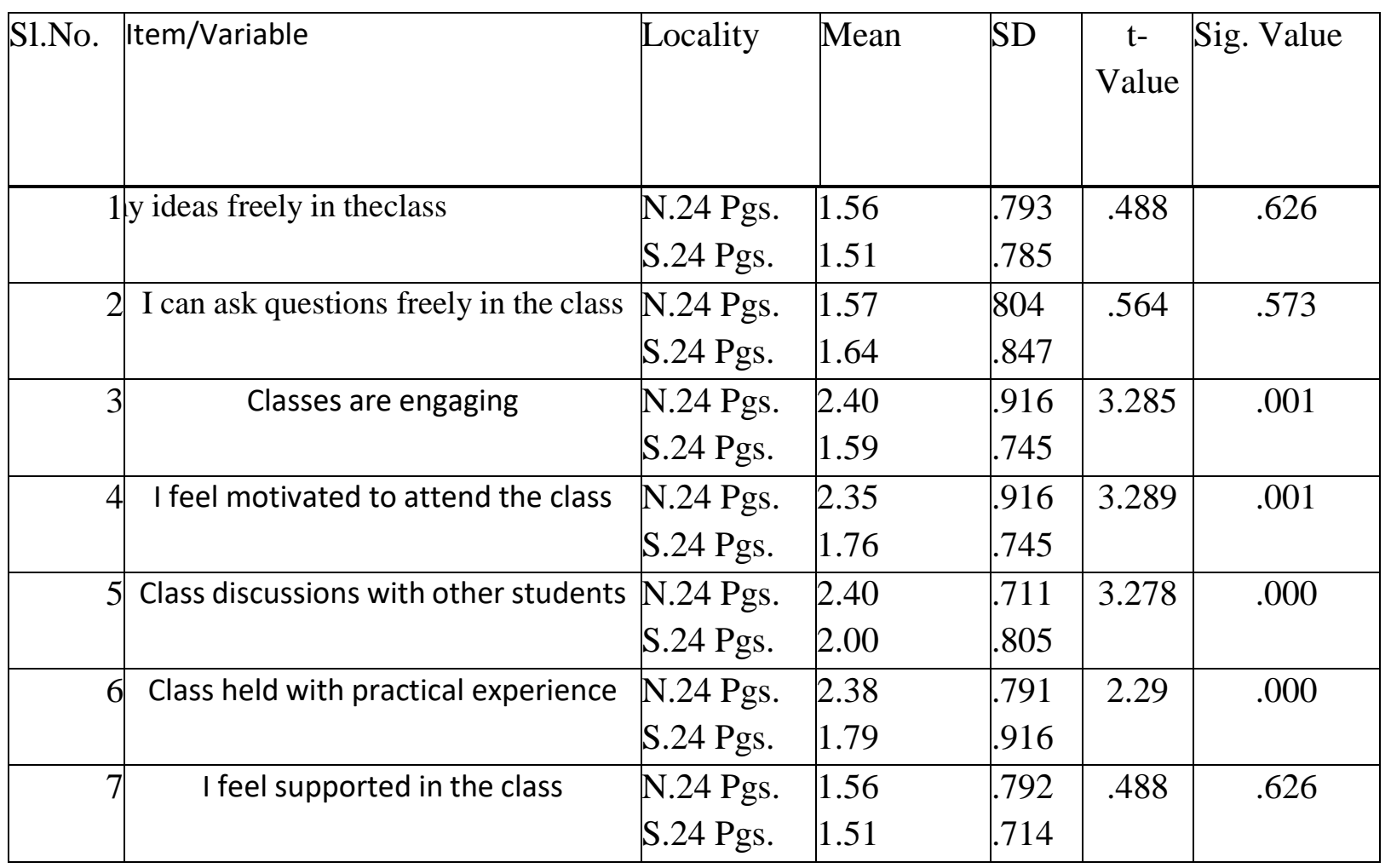

Source: SPSS Software

From the table 2, it is found that both the localities of students does not vary significantly in discussing ideas freely in the class with $\mathrm{t}(199)=.488$, $\mathrm{p}$ value is greater than 0.05 , which suggest that significant difference does not exist between the groups. Both the groups does not vary significantly in asking questions freely in the class with $t(199)=.564$, p value is greater than 0.05 , which suggest that significant difference does not exist between the groups. In classroom engagingwork, the group vary significantly with $t(199)=.3 .285$, $p$ value is lesser than 0.05 , which suggestthat significant difference exist between the groups. The students of north 24 Parganas feel more engaged than the south 24 Pargana with mean and S.D. $2.40 \pm .916$ and $1.59 \pm .745$ respectively. As students of north 24 Pargana feel more engaged in the class, as a result they are more motivatedso the groups vary significantly with $t(199)=3.289$, p value is lesser than 0.05, which suggest thatsignificant difference exist between the groups with leading mean with $2.35 \pm .916$, mean and S.D.In related to classroom discussion with other students both groups not vary with $\mathrm{t}(199)=.3 .278$, pvalue is lesser than 0.05 . The north 24 Parganas students participate more in online discussion, debates, demonstration more actively than the south one. They also gain more practical and live experiences which results in significant difference between the groups with $\mathrm{t}(199)=2.29$, p value is lesser than 0.05. In relation to student support feeling in the class the group does not vary significantly with $t(199)=.488$, p value is greater than 0.05. This is because there are some students who stated that the students who are more active in the class teachers preference is morefor them. The teacher hardly gets time to reach each students individually and conducts discussions with them separately so students who remain engaged and can follow the class they felt supported. 


\subsection{Pertaining to hypothesis 2}

$\mathrm{H}_{\mathrm{o} 2}$ : There is no significant difference in learner's mean scores on online experience in respect oflocality.

To test the hypothesis t-test used by the investigator, which showed in the table 3 .

Table 3: Showing the Online experience of learners in respect of locality

\begin{tabular}{|c|c|c|c|c|c|c|}
\hline Sl.No. & Item/Variable & Locality & Mean & SD & 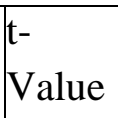 & $\begin{array}{l}\text { Sig. } \\
\text { Value }\end{array}$ \\
\hline 1 & $\begin{array}{l}\text { I can get information about the course } \\
\text { requirements easily. }\end{array}$ & $\begin{array}{l}\text { N.24 Pgs. } \\
\text { S.24 Pgs. }\end{array}$ & $\begin{array}{l}2.15 \\
1.91\end{array}$ & .754 & 2.347 & .002 \\
\hline 2 & $\begin{array}{l}\text { I receive timely feedback from my } \\
\text { instructors on all the assigned work }\end{array}$ & $\begin{array}{l}\text { N.24 Pgs. } \\
\text { S.24 Pgs. }\end{array}$ & $\begin{array}{l}1.78 \\
1.77\end{array}$ & $\begin{array}{l}.808 \\
.809\end{array}$ & 105 & 917 \\
\hline 3 & $\begin{array}{l}\text { The online teaching application used in } \\
\text { the classes is user friendly }\end{array}$ & $\begin{array}{l}\text { N.24 Pgs. } \\
\text { S.24 Pgs. }\end{array}$ & $\begin{array}{l}1.56 \\
1.51\end{array}$ & $\begin{array}{l}.798 \\
.765\end{array}$ & 488 & .626 \\
\hline 4 & $\begin{array}{l}\text { It is easy to meet my instructor during } \\
\text { office hours }\end{array}$ & $\begin{array}{l}\text { N.24 Pgs. } \\
\text { S.24 Pgs. }\end{array}$ & $\begin{array}{l}2.30 \\
1.93\end{array}$ & $\begin{array}{l}.743 \\
.987\end{array}$ & 3.150 & .002 \\
\hline 5 & $\begin{array}{l}\text { It is easy to communicate with my } \\
\text { instructor in synchronous sessions }\end{array}$ & $\begin{array}{l}\text { N.24 Pgs. } \\
\text { S.24 Pgs. }\end{array}$ & $\begin{array}{l}2.45 \\
1.99\end{array}$ & $\begin{array}{l}.756 \\
.956\end{array}$ & 2.47 & .003 \\
\hline 6 & $\begin{array}{l}\text { It is easy to communicate with other } \\
\text { students in online sessions }\end{array}$ & $\begin{array}{l}\text { N.24 Pgs. } \\
\text { S.24 Pgs. }\end{array}$ & 2.40 & $\begin{array}{l}.711 \\
.805\end{array}$ & 2.47 & .000 \\
\hline 7 & $\begin{array}{l}\text { It is easy to collaborate with other } \\
\text { students for group work }\end{array}$ & $\begin{array}{l}\text { N.24 Pgs. } \\
\text { S.24 Pgs. }\end{array}$ & $\begin{array}{l}2.22 \\
1.94\end{array}$ & $\begin{array}{l}.890 \\
.893\end{array}$ & 3.657 & .002 \\
\hline
\end{tabular}

\section{Source: SPSS Software}

From the table 3 it is found that, both the localities of students vary significantly with $t$ (199) $=2.347, \mathrm{p}$ value is lesser than 0.05 , which suggest that significant difference exist between the groups in respect of getting information about the course requirements. The students of north 24 Parganas get information about the course requirements than the south 24 Pargana with mean and S.D. $2.15 \pm .754$ and $1.91 \pm .980$ respectively. In using the user-friendly online teaching applicationboth the groups does not vary significantly with $t(199)=.488, \mathrm{p}$ value is greater than 0.05 . The students of north 24 Parganas can meet with instructor during office hours in online mode to cleartheir doubts. They can even clear their doubts in an online mode, which facilitates them with betteronline experience. So the group vary significantly with $t(199)=$ 2.47 , $p$ value is lesser than 0.05 . They even have easy communicative sessions where the group again vary significantly with $\mathrm{t}(199)=2.47$, p value is less than 0.05 . The students of north 24 Parganas collaborate with students in- group work in compare to south 24 Parganas. So the group vary significantly with $\mathrm{t}(199)=3.657$,p value is lesser than 0.05 . It is because the school of north 24 Parga in recent days are taking the advantages of ICT in administrative functioning 
like filling up of various scholarship related forms for the students, updating school related information to the concerning authorities or maintaining of school data base including pay rolls and so on. Demonstrating various subjects using projector, or KYAN not only helps the students to understand the subject better but the teachers too. Its audiovisual impact attracts the students to be more attentive.

\subsection{Pertaining to hypothesis 3}

Ho3: The online study habits of learners is independent of locality.

To test the hypothesis t-test used by the investigator, which showed in the table 4 .

Table 4: Showing the online study habits of learners based on their locality

\begin{tabular}{|c|c|c|c|c|c|c|c|}
\hline S1.No. & Item/Variable & Locality & Yes & Sometimes & No & $\mathrm{X}^{2}$ & Sig.Value \\
\hline \multirow[t]{2}{*}{1} & \multirow[t]{2}{*}{ otes accuratelyin class. } & N.24 Pgs. & 26 & 31 & 44 & & \multirow[t]{2}{*}{.042} \\
\hline & & S.24 Pgs. & 12 & 39 & 49 & 6.336 & \\
\hline \multirow[t]{2}{*}{2} & \multirow[t]{2}{*}{ I take naps during class. } & N.24 Pgs. & 18 & 41 & 42 & & \multirow[t]{2}{*}{.000} \\
\hline & & S.24 Pgs. & 31 & 64 & 05 & 37.611 & \\
\hline \multirow[t]{2}{*}{3} & \multirow{2}{*}{$\begin{array}{l}\text { I look at my cellphone or } \\
\text { send text messagesduring } \\
\text { class }\end{array}$} & N.24 Pgs. & 53 & 26 & 22 & & \multirow[t]{2}{*}{.000} \\
\hline & & S.24 Pgs. & 47 & 48 & 05 & 17.60 & \\
\hline \multirow[t]{2}{*}{4} & \multirow[t]{2}{*}{ books other thantextbook. } & N.24 Pgs. & 18 & 41 & 42 & & \multirow[t]{2}{*}{.000} \\
\hline & & S.24 Pgs. & 31 & 64 & 05 & 37.611 & \\
\hline \multirow[t]{2}{*}{5} & \multirow[t]{2}{*}{ out during class. } & N.24 Pgs. & 61 & 26 & 10 & & \multirow[t]{2}{*}{.000} \\
\hline & & S.24 Pgs. & 52 & 38 & 10 & 21.253 & \\
\hline \multirow[t]{2}{*}{6} & \multirow{2}{*}{$\begin{array}{l}\text { I actively participate in } \\
\text { work }\end{array}$} & N.24 Pgs. & 30 & 11 & 56 & & \multirow[t]{2}{*}{.000} \\
\hline & & S.24 Pgs. & 09 & 40 & 51 & 31.255 & \\
\hline \multirow[t]{2}{*}{7} & \multirow[t]{2}{*}{ homework ontime. } & N.24 Pgs. & 26 & 31 & 44 & & \multirow[t]{2}{*}{.042} \\
\hline & & S.24 Pgs. & 12 & 39 & 49 & 6.336 & \\
\hline \multirow[t]{2}{*}{8} & \multirow{2}{*}{$\begin{array}{l}\text { prepare for classes } \\
\text { hand and reviewwhat I } \\
\text { have learned. }\end{array}$} & N.24 Pgs. & 26 & 31 & 44 & & \multirow[t]{2}{*}{.042} \\
\hline & & S.24 Pgs. & 12 & 39 & 49 & 6.336 & \\
\hline \multirow[t]{2}{*}{9} & \multirow{2}{*}{$\begin{array}{l}\text { I actively study without } \\
\text { told at home. }\end{array}$} & N.24 Pgs. & 31 & 64 & 5 & 37.611 & \multirow[t]{2}{*}{.000} \\
\hline & & S.24 Pgs. & 18 & 41 & 45 & & \\
\hline \multirow[t]{2}{*}{10} & \multirow{2}{*}{\multicolumn{2}{|c|}{$\begin{array}{l}\text { I take permission of N.24 Pgs. } \\
\text { instructor during class forS.24 Pgs. } \\
\text { excusing for a } \\
\text { while. }\end{array}$}} & 1 & 26 & 74 & 11.377 & \multirow[t]{2}{*}{.078} \\
\hline & & & 0 & 48 & 52 & & \\
\hline
\end{tabular}

Source: SPSS Software 
From the table 4 it is found that, in respect of online habits for taking notes during the class there is significant difference between the groups with $X^{2}$ value $=6.336$ and $p$ value .042 . the students from south 24 Parganas are more fond of taking nap during their class so both the groups vary significantly with $\mathrm{X}^{2}$ value $=37.611$ and $\mathrm{p}$ value .000 . The group vary in respect of in respect of looking at their cellphone or send text messages during class with $\mathrm{X}^{2}$ value = 17.60 and $\mathrm{p}$ value .000 . In respect of reading books other than textbook the group vary significantly with $\mathrm{X}^{2}$ value $=37.611$ and $\mathrm{p}$ value .000 . During the class they even space out in their homerooms, which indicatesthat they devoid the classroom mannerism and habits, which is found significantly within the groups where $X^{2}$ value $=21.253$ and $p$ value .000 . When the individuals feel motivated and interested they will actively participate in-group work. The learners differ significantly in respectof group with $X^{2}$ value $=31.255$ and $p$ value .000 . The group vary significantly in respect of completion of homework on time with $\mathrm{X}^{2}$ value $=6.336$ and $\mathrm{p}$ value .042 . The students from north 24 Parganas mostly prepare for classes beforehand and review what they have learned as becausetheir online activities occur more frequently, so the group vary significantly with $\mathrm{X}^{2}$ value $=6.336$ and $\mathrm{p}$ value .042 . The students of north locality more punctual in respect of studying in home without being told by their caregivers so the group vary significantly with $\mathrm{X}^{2}$ value $=37.611$ andp value .000 . Only in case of taking permission of instructor during class for excusing for a whileboth the group does not vary significantly with $\mathrm{X}^{2}$ value $=11.377$ and $\mathrm{p}$ value .078 . It is because both the group switch off their videos on the time of excusing themselves from the online class.

\subsection{Pertaining to hypothesis 4}

Ho4: There is no significant relationship between online engagement and online learning experiences of learners.

To test the hypothesis t-test used by the investigator, which showed in the table 5 .

Table 5: Showing the online study habits of learners based on their locality

\begin{tabular}{|c|c|c|c|c|}
\hline \multicolumn{3}{|l|}{ Online Engagement } & $\begin{array}{l}\text { Online } \\
\text { Learning } \\
\text { experience }\end{array}$ & $\begin{array}{l}\text { Online } \\
\text { Study } \\
\text { Habits }\end{array}$ \\
\hline \multirow[t]{3}{*}{ Online Engagement } & Pearson Correlation & 1 & $.873^{* *}$ & .718 \\
\hline & Sig. (2-tailed) & & .000 & .000 \\
\hline & $\mathrm{N}$ & 201 & 201 & 201 \\
\hline \multirow{3}{*}{$\begin{array}{l}\text { Online Learning } \\
\text { experience }\end{array}$} & Pearson Correlation & $.873^{* *}$ & 1 & $.821^{*}$ \\
\hline & Sig. (2-tailed) & .000 & & .048 \\
\hline & $\mathrm{N}$ & 201 & 201 & 201 \\
\hline \multirow[t]{3}{*}{ Online StudyHabits } & Pearson Correlation & .718 & .821 & 1 \\
\hline & Sig. (2-tailed) & .000 & .048 & \\
\hline & $\mathrm{N}$ & 201 & 201 & 201 \\
\hline
\end{tabular}

**. Correlation is significant at the 0.01 level (2-tailed).

*. Correlation is significant at the 0.05 level (2-tailed).

Source: SPSS Software 
From the table 5, it displayed that, the correlation between the variables are highly positive. The highest correlation found between online engagement and online learning experience $(\mathrm{r}=.873)$. Sopositive relationship prevails between variables. The online student engagement particularly influenced by a sense of belonging to the institutional, programme and module community. The two factors that can support the development of a sense of community and belonging in students are establishing social presence and high levels of interaction in the course. Developing social presence in the course gives students a greater sense of connection to each other, the teacher and the course. Interaction and social presence promoted through course design, which promotes activecommunication between students and instructors using asynchronous discussion forums and synchronous online classes. The more the students are engaged in the online mode the more positive online experience develop between them.

\subsection{Pertaining to hypothesis 5}

Hos: There is no significant relationship between online engagement and online study habits oflearners.

From the table 5, it displayed that, the correlation between the variables are highly positive. The correlation found between online engagement and online study habits of learner is positively related $(\mathrm{r}=.718)$. This engagement give them positive motivation and train them in self-discipline.In having study habits like Time Scheduling, Concentration, Listening and Note taking, hence, found in learners, which help them to connect with the course module. The more the students areengaged in the online mode the more positive healthy habits develop between them.

\subsection{Pertaining to hypothesis 6}

Ho6: There is no significant relationship between online learning experiences and online study habits

From the table 5, it displayed that, the correlation between the variables are highly positive. The correlation found between online learning experience and online study habits of learner is positively related $(r=.821)$. Students who have positive experiences are more likely to reenroll in online courses in the future, so an institution that seeks to increase online enrollment would benefitfrom such information. Data about student experiences also can provide information to help institutions and faculty design and deliver better courses, which could help improve student learning in these courses. Such data also could help institutions and faculty to determine what challenges students face in online mode, which could in turn improve persistence and retention inonline courses. The more the students are getting positive experiences in the online mode the morepositive healthy habits develop between them.

\section{Conclusion}

From the higher than discussion, it over that on-line study habit incorporates a profound impact on learning expertise and on-line engagement. The school authorities ought to style and set up courses during a systematic means. Students ought to have smart opportunities to attach with peersand instructors in on-line discussions, debates, symposiums, pairing activities, etc., it's not solely with presenting the content on the net platform and finishing the course content by 
touching the shreds of content. However, most significantly victimization the ICT during a even handed meansby presenting the content meaningfully, into completely different sections. Every section of the sub-content substantively connected during a successive manner in order that they realize the content meaningful. Instructors additionally had a robust influence over student expertise, in massive half through their accessibility and thru their efforts to produce opportunities to attach with peers. Sadly, not all students had positive experiences with their instructors, and so their on-line experiences suffered. Students who lack positive study habits steering and direction services on the formation of excellent study habits ought to organized throughout their orientation programat the beginning of their incoming into the online program.

\section{References}

- Akdemir, O., \& Koszalka, T. A. (2008). Investigating the relationships among instructional strategies and learning styles in online environments. Computers \& Education, 50(4), 14511461.

- Akkoyunlu, B., \& Soylu, M. Y. (2008). A study of student's perceptions in a blended learning environment based on different learning styles. Educational Technology \& Society, 11(1), 183193.

- Allen, M., J. Bourhis, N. Burrell, \& E. Mabry. (2002). Comparing student satisfaction with distance education to traditional classrooms in higher education: A met analysis. The American Journal of Distance Education, 16(2), 83-97.

- Ally, M., \& Fahy, P. (2002, August). Using students' learning styles to provide support in distance education. In Proceedings of the Eighteenth Annual Conference on Distance Teaching and Learning, Madison, WI.

- Aragon, S. R., Johnson, S. D., \& Shaik, N. (2002). The influence of learning style preferences on student success in online versus face-to-face environments. The American Journal of Distance Education, 16(4), 227-243.

- Aşkar, P., \& Akkoyunlu, B. (1993). Kolb learning style inventory. Education and Science,15 (81), 37-47.

- Benbunan-Fich, R., \&S. R. Hiltz. (2003). Mediators of the effectiveness of online courses.IEEE Transactions on Professional Communication, 46(4), 298-312.

- Chen, N. S., \& Lin, K. M. (2002, September). Factors affecting e learning for achievement.In IEEE International Conference on Advanced Learning Technologies (9-12).

- Coffield, F., Moseley, D., Hall, E., \& Ecclestone, K. (2012). Learning styles and pedagogyin post-16 learning: A systematic and critical review. Learning and Skills Research Centre: London.

- Cohen, J. (1988). Statistical power analysis for the behavioral sciences (2nd ed.) Hillsdale, NJ: Lawrence Erlbaum Associates.

- Coleman, P., Collinge, J., \& Tabin, Y. (1993). The Learning triad: Parental involvement. London: University of North London Press.

- Crede, M., \& Kuncel, N. R. (2008). Study habits, skills, and attitudes: The third pillar supporting collegiate academic performance. Perspectives on Psychological Science, 3, 425454. 